\title{
A study of size of nutrient foramina of humerus of Gujarat region
}

\author{
Bhavik Doshi ${ }^{1}$, Hemang Joshi ${ }^{2, *}$, Shailesh Patel ${ }^{3}$ \\ ${ }^{\mathbf{1}}$ Associate Professor, ${ }^{2}$ Tutor, ${ }^{3}$ Professor \& Head, Dept. of Anatomy, ${ }^{\mathbf{1}}$ GMERS Medical College, Sola, \\ Ahmedabad, ${ }^{2,3}$ Government Medical College, Bhavnagar, Gujarat, India
}

*Corresponding Author:

Email: joshihemang30@yahoo.com

\begin{abstract}
Delayed union or non-union of fracture shaft humerus occurs if there is damage to nutrient artery of humerus during surgical procedure of open reduction of fracture or by displaced bone fragments of fracture or any soft tissue interposition. This implies vital role of nutrient artery of humerus in fracture healing. 200 human dried humeri were studied for its anatomy of size and number of nutrient foramina. Size of nutrient foramen and thereby size of nutrient artery was decided with use of hypodermic needle No. 20 G \& No. 24 G from Eastern medikit Limited. Observations made were compiled and tabulated. In present study, out of 282 nutrient foramina, 98 $(35 \%)$ were large sized. Single nutrient foramina were found on $63 \%$ of humerus which is indicative of single nutrient artery to humerus and amongst them $40 \%$ humerus having large sized nutrient foramina. $65 \%$ of large sized nutrient dominant foramina were found on humerus having more than one nutrient foramina. 60 (49\%) large sized nutrient foramina were found on right side humerus which is points to more use of right arm. Orthopaedic surgeons treating opened or displaced fracture shaft humerus can very well prevent damage to nutrient artery of humerus with sound knowledge of size of nutrient foramina and thereby its artery and add to better prognosis of fracture healing.
\end{abstract}

Received: $22^{\text {nd }}$ September, 2017

Accepted: $19^{\text {th }}$ December, 2017

\section{Introduction}

The nutrient artery of medulla is the main source of blood supply of diaphyseal cortex where as the periosteal arteries supplies the outer shell of cortex and take part in anastomosis with medullary arteries. ${ }^{1}$ The nutrient artery to humerus, in one or two numbers, is branches of profunda brachii artery. ${ }^{2}$ The nutrient artery enters into shaft with almost constant angulation\& then in medullary cavity it divides into ascending \& descending branches. The direction of nutrient foramina is away from growing end so here it is towards lower end of humerus. Inner $2 / 3$ or more of diaphyseal cortex is supplied by nutrient artery and outer cortex is supplied by periosteal artery. After $12^{\text {th }}$ year, the red bone marrow begins to recede from diaphyses of long bone. So this leads to periosteum less vascular and the medullary nutrient artery becomes the main vascular source. ${ }^{3}$ Major nutrition to humerus is provided by medullary nutrient artery. Loss of blood supply is the major causative factor for delayed or non-union of fracture of shaft humerus. Refracture is very common if fracture in phase of delayed union is stressed. This indicates vital role of nutrient artery in uniting callus \& reperfusion of necrotic cortex of fracture shaft humerus ${ }^{1}$. Uninterrupted blood supply by nutrient artery is required for healing of a bone fracture; which if not, leads to develop slowly or not at all. ${ }^{4}$ For this reason knowledge of detailed anatomy of size of nutrient artery /arteries makes its significant role in this study.

\section{Materials and Methods}

In this study 200 dried humeri were examined. They were collected from department of anatomy of various medical colleges of Gujarat region. Humeri used in study were not necessarily paired, of unknown age \& of unknown sex. Humerus having altered pathology and defects were excluded in study. All humeri were examined for number and size of nutrient foramina on its surface. To study the size of nutrient foramen or foramina (in case of more than one foramen), the hypodermic needle were used. The hypodermic needles No. $20 \mathrm{G} \&$ No. $24 \mathrm{G}$ of Eastern Medikit Limited were used ${ }^{5}$. Every nutrient foramen examined twice for size of nutrient foramina by two (2) examiners and observations thus made were tabulated by following way.

If nutrient foramen admits of No. $20 \mathrm{G}$ needle: denotes LARGE size nutrient foramen

If nutrient foramen admits only No. $24 \mathrm{G}$ needle: denotes MEDIUM size nutrient foramen If nutrient foramen does not admit No. $24 \mathrm{G}$ needle: denotes SMALL size nutrient foramen

In case of more than one nutrient foramina were found on shaft of humerus the larger nutrient foramen was considered as dominant. ${ }^{5}$ 
Observations found were tabulated and compiled. Necessary statistical study and analysis were done by using application of calculating standard deviation, fisher's " $t$ " table, or by calculating the standard error of difference between

proportions.

\section{Results}

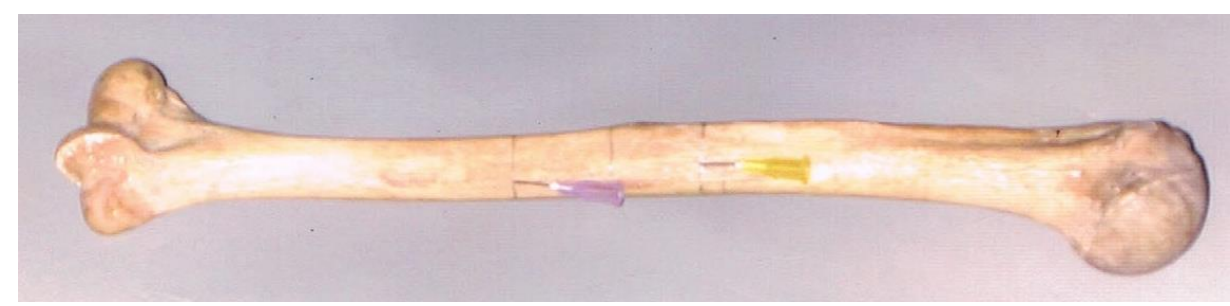

Fig.1: Various sizes of Nutrient foramina of humerus - Large size (admitting No. 20 G needle, yellow colored) and Medium size (admitting No. 24 G needle, purple colored)

Out of 200 humeri examined in this study, a single nutrient foramen found in 126 humerus, two nutrient foramina found in 66 humerus \& three nutrient foramina found in 8 humerus.

Table1: Size of nutrient foramina of humerus

\begin{tabular}{|l|c|c|c|}
\hline $\begin{array}{c}\text { Size of nutrient } \\
\text { foramina }\end{array}$ & $\begin{array}{c}\text { Right sided } \\
\text { humerus }\end{array}$ & $\begin{array}{c}\text { Left sided } \\
\text { humerus }\end{array}$ & $\begin{array}{c}\text { Total no. of } \\
\text { nutrient foramina }\end{array}$ \\
\hline Small & 22 & 32 & 54 \\
\hline Medium & 40 & 90 & 130 \\
\hline Large & 60 & 38 & 98 \\
\hline Total & $\mathbf{1 2 2}$ & $\mathbf{1 6 0}$ & $\mathbf{2 8 2}$ \\
\hline
\end{tabular}

Table 1 shows size of nutrient foramina of humerus where 98 (35\%) were large sized nutrient foramina. Presence of $49 \%$ large foramina in right humeri \& 56\% medium sized foramina in left humeri are in higher proportion and it proved to statistically significant.

Table 2: Size of dominant nutrient foramen of humerus

\begin{tabular}{|l|c|c|c|}
\hline $\begin{array}{c}\text { Size of Dominant } \\
\text { nutrient foramina }\end{array}$ & $\begin{array}{c}\text { Right } \\
\text { Humerus }\end{array}$ & $\begin{array}{c}\text { Left } \\
\text { Humerus }\end{array}$ & $\begin{array}{c}\text { Total no. of } \\
\text { humerus }\end{array}$ \\
\hline Small & 6 & 10 & 16 \\
\hline Medium & 20 & 66 & 86 \\
\hline Large & 60 & 38 & 98 \\
\hline Total & $\mathbf{8 6}$ & $\mathbf{1 1 4}$ & $\mathbf{2 0 0}$ \\
\hline
\end{tabular}

Table 2 indicates that right sided humerus is having $61 \%$ of Large Dominant nutrient foramina \& left sided humerus is having $76 \%$ of medium sized dominant foramina. These results are statistically significant.

Table 3: Humerus having Single dominant nutrient foramen

\begin{tabular}{|l|c|c|}
\hline \multicolumn{1}{|c|}{$\begin{array}{c}\text { Size of dominant nutrient } \\
\text { foramina }\end{array}$} & $\begin{array}{c}\text { Right sided } \\
\text { humerus }\end{array}$ & $\begin{array}{c}\text { Left sided } \\
\text { humerus }\end{array}$ \\
\hline Small & 6 & 10 \\
\hline Medium & 16 & 44 \\
\hline large & 32 & 18 \\
\hline Total & $\mathbf{5 4}$ & $\mathbf{7 2}$ \\
\hline
\end{tabular}

Table 3 shows that out of 200 humeri examined in present study, single nutrient foramina were found on 54 right humeri and 72 left humeri. Out of these 126 humeri, 50 humeri (40\%) have large sized nutrient foramina. More no. of single large size dominant foramina (32) on right side and more no. of single medium size dominant foramina (44) on left side are proved to be statistically significant. 


\section{Discussion}

One of the major complications in fracture shaft humerus is non-union. Non-union \& delayed union of fracture shaft humerus can be dealt with great result after having detailed knowledge of nutrient artery of humerus. Nutrition in the form of blood supply plays very vital role in healing of fractures..$^{3,6,7}$ The faulty union of fracture bone may be due to injury to nutrient artery at time of fracture reduction or its subsequent procedure. ${ }^{8-12}$ Chances of these complications can be lessened to a great extent by exercising care in preventing damage to nutrient artery of humerus during operations.

Table 4: Comparative study of size of nutrient foramina of humerus

\begin{tabular}{|l|c|c|}
\hline $\begin{array}{c}\text { Size of Nutrient } \\
\text { Foramina }\end{array}$ & S.E. Carroll & Present Study \\
\hline Small & $15(15 \%)$ & $54(19 \%)$ \\
\hline Medium & $45(46 \%)$ & $130(46 \%)$ \\
\hline Large & $37(38 \%)$ & $98(35 \%)$ \\
\hline
\end{tabular}

Table 4 shows that out of 282 nutrient foramina, 98 (35\%) were large sized which matches with study of S.E.Carroll ${ }^{5}$ who found this in $38 \%$.

Table 5: Comparative study of numbers of nutrient foramina of humerus

\begin{tabular}{|l|c|c|c|}
\hline $\begin{array}{l}\text { No. of nutrient } \\
\text { foramina found } \\
\text { on humerus }\end{array}$ & $\begin{array}{c}\text { S.E. } \\
\text { Carroll }^{5}\end{array}$ & $\begin{array}{c}\text { P.G. } \\
\text { Laing }^{8}\end{array}$ & $\begin{array}{c}\text { Present } \\
\text { study }\end{array}$ \\
\hline ONE & $48(68 \%)$ & $28(93 \%)$ & $126(63 \%)$ \\
\hline TWO & $20(28 \%)$ & $2(7 \%)$ & $66(33 \%)$ \\
\hline THREE & $3(4 \%)$ & - & $8(4 \%)$ \\
\hline
\end{tabular}

It is evident from Table 5 that more numbers of humeri had single nutrient artery and preventing damage to it leads to lesser chances of decrease blood supply to healing fracture.

Table 6: Comparative study of size of Dominant nutrient foramina of humerus

\begin{tabular}{|l|c|c|}
\hline $\begin{array}{c}\text { Size of nutrient } \\
\text { foramina }\end{array}$ & S.E. Carroll $^{\mathbf{5}}$ & Present study \\
\hline Small & $5(7 \%)$ & $16(8 \%)$ \\
\hline Medium & $29(41 \%)$ & $86(43 \%)$ \\
\hline Large & $37(52 \%)$ & $98(49 \%)$ \\
\hline
\end{tabular}

Proportion of large and medium sized nutrient foramina in Carrroll's study matches with present study. In present study we found 60 (49\%) large sized nutrient foramina on right sided humerus which almost match with the study of S. E. Caroll who found $25(50 \%)$ large sized nutrient foramina in right humerus. Right humerus contains 20 (33\%) medium sized nutrient foramina in present study which was 9 (25\%) in study of S. E. Caroll. The large size nutrient foramina in left humerus in present study and in study by S.E. Caroll are $38(24 \%) \&$ $12(34 \%)$ respectively. In present study, medium sized nutrient foramina in left humerus are $66(56 \%)$ which match with the study of S. E. Caroll who found this in $20(57 \%)$ in left humerus. More large sized foramina in right sided humerus \& more medium sized foramina in left sided humerus is may be due to more blood supply is required to right sided humerus because of more use of right arm and also more right handed persons are there. This has to be studied further for evaluation.

\section{Conclusion}

Large number of humerus has single nutrient foramina suggestive of single nutrient artery fulfilling nutritional requirement. More number of large sized nutrient foramina in above humerus suggestive of large sized single nutrient artery supplying shaft of humerus which should be preserved during surgical intervention. More number of large sized dominant nutrient foramina in right sided humerus indicates more use of right arm which is dominant one. Again major proportion of single medium sized nutrient foramina on left sided humerus leaves a further scope of study of size of nutrient foramina present in same handedness individual. 


\section{Acknowledgements}

We are very thankful to Dr. S. S. Bhagwat, Late Dr. D. C. Vyas, Dr. B. B. Gosai and my colleagues and friends at Anatomy Deparment of various medical colleges for helping us in this study.

\section{References}

1. Rhinelander FW - The normal microcirculation of diaphyseal cortex and its response to fracture. Journal of Bone \& Joint Surgery 1927, vol. 50A, page no. 643-62.

2. Gray's Textbook of Anatomy $-37^{\text {th }}$ edition 1993 , page no. 299-300,759.

3. Woodjones F. - Buchanan's Manual of Anatomy (1946); $7^{\text {th }}$ edition, page no. 87-8, 280.

4. Turek, S. L - Orthopaedics, Principles \& Their Application 2004. Philadelphia and Montreal: J. B. Lippincott Company, page no. 59-60.

5. Carroll S E. - A Study of Nutrient Foramina of the Humeral Diaphysis, The journal of Bone \& Joint Surgery 1963; vol. 45B, page no. 176-81.

6. Johnson, R. W. - A Physiological study of the Blood Supply of the Diaphysis, Journal of Bone \& Joint Surgery 1927,9, 153.

7. Coolbaugh, C. C - Effects of Reduced Blood Supply of bone. American Journal of Physiology 1952, 169, 26.

8. Laing P G. - The Arterial supply of Adult Humerus, The Journal of bone \& Joint Surgery 1956; Vol.38A, page no. 1105-16.

9. Stewart, M. J and Hundley, J. M - Fractures of the Humerus; a Comparative Study in Methods of Treatment. Journal of Bone and Joint Surgery 1955, 37-A, 681.

10. Watson-Jones, Sir R. - Fractures and Joint Injuries 1955. $4^{\text {th }}$ Edition. Edinburgh and London: E. \& S. Livingstone Ltd.

11. Kennedy, J. C., Wyatt, J. K. - An Evaluation of the Management of Fractures through the Middle Third of the Humerus. Canadian Journal of Surgery 1957, 1, 26.

12. Mercer, Sir W. - Orthopaedic Surgery 1959. $5^{\text {th }}$ edition. London: Edward Arnold (Publishers) Ltd. 